\title{
LAND USE PLANNING AND HOUSING SITUATION IN THE WA AND OFFINSO SOUTH MUNICIPALITIES, GHANA BOAMAH, N.A. \\ http://dx.doi.org/10.4314/ejesm.v6i4.13
}

Received 20th April 2013; accepted 5th July 2013

\begin{abstract}
Housing insufficiency is a major problem confronting most Ghanaian households. The paper examines the state of housing in the Wa and the Offinso South municipalities of Ghana. It investigates the liveability of housing in these municipalities. The housing adequacy across the municipalities is compared. One hundred and twenty housing units in each municipality were surveyed for data gathering. The units of enquiry were the households' heads and property owners. Questionnaires were used to obtain data from respondents. It finds that most of the houses surveyed lack basic facilities. It notes that most households in the municipalities lack adequate housing. The paper observes statistically significant difference in the room occupancy rates, flooring materials, households' access to toilet facilities, mode of disposing liquid waste, and quality of bathing facilities across the municipalities. The paper however, finds no statistically distinguishable difference between the quality of outer wall, roofing materials, drinking water quality and solid waste disposal modes in the municipalities. Again, non-adherence to planning regulations is partly responsible for the state of housing in the municipalities. The paper notes that deprived housing conditions have significant negative impact on protected lands and environmentally vulnerable areas of the municipalities. It recommends the use of both social force and the legal regime to discourage environmentally unfriendly acts in the municipalities. Again, it recommends the enforcement of regulations on the provision of in-house toilet and bathing facilities and de-emphasizing of public toilets delivery.
\end{abstract}

Key words Housing Situation, Housing Infrastructure, Planning Regulations, Wa, Offinso-South, Ghana

\section{INTRODUCTION}

Housing plays a significant role in the development and survival of the human race. Inadequate housing exposes a nation's population to one of the greatest problems and inconveniences in life (Owusu and Boapeah, 2003). Rising affordability problems may lead to involuntary displacement of low-income households (Galster and Tatian, 2009). Declining home ownership has negative repercussions for households' savings capability (Heywood, 2011). Housing conditions significantly influence the health status of individuals (Bonnefoy et al., 2003). Neighborhood quality impacts not only on the quality of life but also on residents' social and economic opportunities (Deng, 2007; Kupke and Rossini, 2011). Housing delivery, affordability, adequacy and access are therefore of great importance to all nations Poor quality housing has the potential to marginalize, create a sense of inadequacy and insecurity, and undermine the mental and emotional stability of households. The majority of low-income dwellers in developing nations are only able to access affordable houses via State interventions (Fawaz, 2009). The housing problem appears to be global in nature.

Insufficient delivery, limited access, and rising affordability concerns characterise the Ghanaian housing sector. Most Ghanaian households live in overcrowded or deteriorating housing units; insanitary living environments; have inadequate access to waste collection and disposal modes and potable water; or "sleep rough" (Obeng-Odoom, 2009; Boamah, 2010; UN-HABITAT, 2010). This is mostly due to economic and political reasons (AsomaniBoateng, 2007). A major nuisance in Ghanaian towns and villages is decayed housing. These housing units pose health, safety and environmental concerns to households. The extent of housing decay is however, severe in the rural relative to the urban centres and more prominent in the urban slums and low-income urban neighbourhoods relative to high-income urban residential areas. Attitudes towards property maintenance, low income levels, and inadequate housing finance mechanisms are 
partly responsible for the state of housing in the country (Adarkwa and Oppong, 2007; Boamah, 2009).

Previous Ghanaian studies have mainly focused on the state of housing in Accra and to a minimal extent Kumasi. There is scanty literature on the condition of housing outside Accra. This paper makes a contribution by helping to fill this gap in the country's housing literature. The paper examines the housing situation in the $\mathrm{Wa}$ and Offinso South municipalities. It analyzes the quality of the living environment, the impact of the land use planning system on the state of housing and the effect of the housing conditions on protected and environmentally sensitive areas of the municipalities. The paper compares the housing experience of households across the two municipalities.

\section{Study Area}

The study areas are the Wa Municipality (WM) and Offinso South municipality (OSM). Wa is the administrative capital of the Upper West Region of Ghana. The WM had a total land area of $5,460 \mathrm{sq}$. $\mathrm{Km}$, and a population of 224,066 persons in 2000 (GSS, 2005). The indigenous people in the WM are the Wala's and the Dagaba's. The OSM is located $17 \mathrm{~km}$ from Kumasi (the administrative capital of the Ashanti Region). The OSM had a total land area of 1,350 sq. $\mathrm{Km}$ and a population of 138,676 persons in 2000 (GSS, 2005). The indigenes in the OSM are the Asantes. The WM and OSM were chosen because they are respectively located in the northern (Upper West Region) and southern (Ashanti Region) sectors of the country, are both cosmopolitan, and have seen rapid growth in recent times. The municipalities therefore permit a comparison of the housing state across different cultural settings.

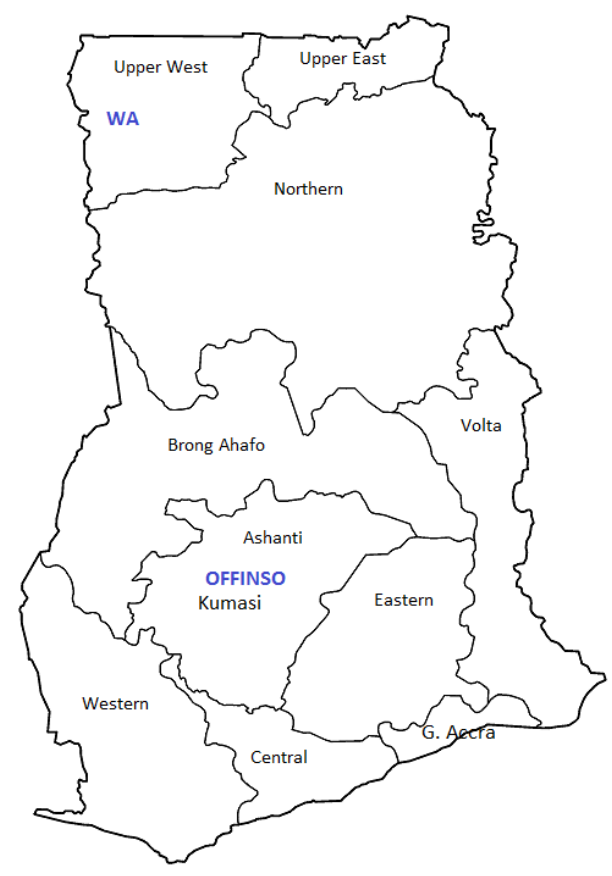

Figure 1 Regional Map of Ghana

\section{Methodology}

Field surveys were carried out in the WM and the OSM to collect empirical data. The study selected eight (8) neighborhoods from each of the municipalities via balloting. This approach eliminated bias in the neighborhoods selection. Fifteen housing units were selected from each of the selected neighborhoods also through balloting. One-Twenty (120) housing units each from WM and OSM were sampled for the study.
Data were obtained from all households in the selected housing units. A total of 306 and 435 households from the WM and the OSM correspondingly were involved in the study. The household heads formed the unit of enquiry. All the property owners from the selected housing units were also involved in the study. Data were obtained from the respondents via self administered structured questionnaire. 
To compare the quality of housing across the municipalities a quality index was constructed for the materials for outer wall, roofing and floor construction; source of drinking water; nature of toilet facilities; and liquid and solid waste disposal means for each municipality. The respondents ranked the quality of the various building materials and housing facilities on a scale of 1 (lowest quality) to $\mathrm{N}$ (highest quality) within each category (e.g. the various flooring materials were ranked from 1 to $\mathrm{N}$ ). The average of the respondents' ranks for each building material or housing facility was estimated. Within each category (e.g. material for outer wall construction), the average ranks were used to assign quality index ranks (from 1 to $\mathrm{N}$ ) to the various materials or facilities. For instance, Cement block was assigned the highest quality index value of 3 and mud/earth walls the lowest quality index value of 1 for the outer-walling material category. Similarly, the toilet type that had the highest and lowest average rank within the household toilet group were respectively assigned the highest and lowest ranks for the quality of toilet facilities index. The various building materials and housing facilities indices (one for each municipality) were evaluated by employing the quality ranks to assign quality index values to the various building materials and housing facilities in the properties surveyed. Each index (e.g. the quality of liquid waste disposal index) had 120 observations; one observation per house.

The approach for constructing the quality indices was employed because the Ghana Building Code (L.I. 1630), 1996 provides no quality classifications for building materials and housing facilities. Also, the approach helped in eliminating our own subjective opinion on what constitutes quality or low quality building material and housing facility. The approach ensured that the quality indices reflected households or housing consumers' expectations and experiences with various construction materials and housing facilities.

\section{Statistical Analyses}

ANOVA and Independent Samples Test were employed to test the equality of these quality indices across the municipalities.

\section{Results and Discussion \\ Housing Affordability, Land Use Planning and Urban Development}

Access to adequate and affordable housing is essential for the attainment of environmentally friendly urban development. Difficulties in accessing housing particularly by the urban poor may facilitate slum formation and may consequently lead to environmental degradation. Housing inadequacy, informal development and unresponsive planning regime may lead to sprawling and unsustainable development. Inadequate housing has exerted pressure on the urban environment of most African countries and consequently threatens the health and wellbeing of urban residents (Boadi et al., 2005).

The environmental impact of housing development is a global concern. Land use and cover conversions constitute major threat to the quality and quantity of freshwater resources (Alcamo et al. 2007; Pavri et al, 2012). Housing development plays a major role in land use conversions and hence the destruction of biodiversity. It is argued that land use planning is essential in curtailing the impact of housing on the environment. Land use policies are employed to control the supply of housing units and to protect sensitive natural resources (Schively, 2008; Coffman and Umemoto, 2011). A land use control may rather facilitate the destruction of environmental sensitive areas. It may "zone out" low and middle income housing and make housing unaffordable to majority of households (Levine, 1998; Whitehead, 2007). This may confine the low-income households to low quality housing and may promote unapproved developments with severe consequences for protected areas and fragile environmental zones. Unapproved developments are partly responsible for the poor environmental conditions in most urban areas in Ghana (Grant and Yankson, 2003).

Housing affordability problems may have consequential environmental outcomes. Housing inadequacy has the potential to worsen the vulnerability of low-income households (Mueller et al., 2011). This may prompt environmentally unfriendly acts such as unauthorized occupation of amenity lands (like wetlands and public space) with substantial outcomes for the quality of the living environment, land values, and the ability of the urban area to withstand natural disasters. Uncontrolled development has made Accra vulnerable to earthquake risk (OtengAbabio, 2012). Karamujic (2011) argue that housing investment serves as an important wealth building activities for a vast majority of households. However, destruction of amenity lands and sensitive environmental zones via unauthorized housing development would slump 
the value of households housing wealth. Such environmentally unfriendly behaviours have serious implications for the sustainability of the urban environment and are hazardous to the urban residents.

Housing shortages may lead to poor land uses and environmental resource degradation. Rapid, unplanned and uncoordinated housing development may lead to significant loss of amenity and fringing arable lands, and degradation of ecosystems (Moore et al., 2003; Lwasa, 2004; Nsiah-Gyabaah, 2004). Lwasa observes that the growth of informal settlements has depleted wetlands and low land forests in and around Kampala city. Uncontrolled housing development has the potential to modify the chemical composition of the atmosphere, and the thermal and hydrological properties of the earth's surface (Olanrewaju, 2009). These may lead to increase temperature, discomfort for mankind, stress and diminished economic productivity of nations.
State of Housing in the Wa and Offinso South Municipalities

\section{Housing Density}

Table 1 indicates statistically significant difference between the room occupancy rates, households per house, and population per house across the municipalities. There is no statistically distinguishable difference between households' size and rooms per house in the OSM and WM. Therefore, the difference in the room occupancy rate between the two municipalities may be due to high households per house and population concentration in the OSM relative to the WM. This may be due to the proximity of the OSM to Kumasi. The OSM is the home to some households working or seeking employment in Kumasi. This appears to have stressed the housing situation in the OSM with significant health implications for households.

Table 1 Households and Housing Characteristics

\begin{tabular}{|c|c|c|c|c|c|c|}
\hline \multicolumn{7}{|c|}{ ANOVA Analyses } \\
\hline & & Sum of Squares & $\mathrm{DF}$ & Mean Square & $\mathrm{F}$ & Sig. \\
\hline \multirow{3}{*}{$\begin{array}{l}\text { Population per } \\
\text { house }\end{array}$} & Between Groups & 1316.02 & 1 & 1316.02 & 11.8 & 0.001 \\
\hline & Within Groups & 26544.32 & 238 & 111.53 & & \\
\hline & Total & 27860.33 & 239 & & & \\
\hline \multirow{3}{*}{$\begin{array}{l}\text { Households } \\
\text { per house }\end{array}$} & Between Groups & 70.42 & 1 & 70.42 & 14.63 & 0.000 \\
\hline & Within Groups & 1145.57 & 238 & 4.81 & & \\
\hline & Total & 1215.98 & 239 & & & \\
\hline \multirow{3}{*}{$\begin{array}{l}\text { Rooms in } \\
\text { house }\end{array}$} & Between Groups & 3.27 & 1 & 3.27 & 0.306 & 0.581 \\
\hline & Within Groups & 2540.32 & 238 & 10.674 & & \\
\hline & Total & 2543.58 & 239 & & & \\
\hline \multicolumn{2}{|c|}{ Household size Between Groups } & 1.663 & 1 & 1.663 & 0.239 & 0.626 \\
\hline & Within Groups & 1651.32 & 237 & 6.968 & & \\
\hline & Total & 1652.99 & 238 & & & \\
\hline \multirow{3}{*}{$\begin{array}{l}\text { Population per } \\
\text { room }\end{array}$} & Between Groups & 35.50 & 1 & 35.499 & 20.99 & 0.000 \\
\hline & Within Groups & 400.76 & 237 & 1.691 & & \\
\hline & Total & 436.26 & 238 & & & \\
\hline
\end{tabular}

\section{Construction Materials}

Generally, housing units in the WM and OSM are made of quality building materials. The WM data show that the outer wall of $77.5 \%$, the roof of $95.0 \%$, and the floor of $90.0 \%$ of the housing units are respectively constructed with cement blocks; corrugated metal sheets; and concrete. In the OSM however, the materials for constructing the outer wall of $70.8 \%$, roof of $96.7 \%$, and floor of $70.8 \%$, of houses are cement blocks; corrugated metal sheets, and concrete correspondingly. The data appears to suggest that relatively households in the WM uses quality material for floor and outer wall construction than households in the OSM. However, the independent samples test in Table 2 indicates no statistically distinguishable difference between the quality of outer wall and roofing materials. The test however, suggests a statistically significant difference at the $10 \%$ level in the quality of flooring materials between the two municipalities. 
Table 2 Quality of Construction Materials

\begin{tabular}{|c|c|c|c|c|c|c|}
\hline \multicolumn{7}{|c|}{ Independent Samples Test } \\
\hline \multirow[t]{2}{*}{$\begin{array}{l}\text { Constructior } \\
\text { Material } \\
\end{array}$} & & \multicolumn{2}{|c|}{$\begin{array}{c}\text { Levene's Test for Equality of } \\
\text { Variances }\end{array}$} & \multicolumn{3}{|c|}{ T-test for Equality of Means } \\
\hline & & $\mathrm{F}$ & Sig. & $\mathrm{t}$ & DF & Sig. (2-tailed) \\
\hline \multirow[t]{2}{*}{ Outer wall } & Equal variances assumed & 4.308 & 0.039 & 1.036 & 238 & 0.301 \\
\hline & $\begin{array}{l}\text { Equal variances not } \\
\text { assumed }\end{array}$ & & & 1.036 & 237 & 0.301 \\
\hline \multirow[t]{2}{*}{ Roof } & Equal variances assumed & 0.239 & 0.625 & 0.427 & 238 & 0.669 \\
\hline & $\begin{array}{l}\text { Equal variances not } \\
\text { assumed }\end{array}$ & & & 0.427 & 209 & 0.670 \\
\hline \multirow[t]{2}{*}{ Floor } & Equal variances assumed & 31.139 & 0.000 & -1.955 & 238 & 0.052 \\
\hline & $\begin{array}{l}\text { Equal variances not } \\
\text { assumed }\end{array}$ & & & -1.955 & 204 & 0.052 \\
\hline
\end{tabular}

\section{Housing Facilities}

A housing facility that lacks basic amenities such as quality drinking water, toilet, bathing, and waste disposal facilities constitutes life and health threat to the occupants and may have dire environmental consequences for an entire neighborhood. Occupants of housing units without toilet and proper waste disposal mechanisms may engage in open defecation and indiscriminate waste disposal. Such activities have serious environmental consequences such as surface and ground water pollution. The field data show that $17.5 \%, 12.5 \%$ and $62.5 \%$ of households' in the WM have no in-house bathhouse; involved in indiscriminate defecation (free range) and uses public toilet respectively. Also, in the OSM, 8.3\%, 20.0\% and $25.8 \%$ of households have no in-house bathing facilities; involved in free range and uses public toilet respectively.

Table 3 Quality of Housing Facilities

\begin{tabular}{|c|c|c|c|c|c|c|}
\hline \multicolumn{7}{|c|}{ Independent Samples Test } \\
\hline \multirow{2}{*}{\multicolumn{2}{|c|}{$\begin{array}{l}\text { Housing } \\
\text { Facilities }\end{array}$}} & \multirow{2}{*}{\multicolumn{2}{|c|}{$\begin{array}{c}\text { Levene's Test for Equality of } \\
\text { Variances }\end{array}$}} & \multirow{2}{*}{\multicolumn{3}{|c|}{ T-test for Equality of Means }} \\
\hline & & & & & & \\
\hline & & $\mathrm{F}$ & Sig. & $\mathrm{t}$ & DF & Sig. (2-tailed) \\
\hline \multirow[t]{2}{*}{ Bathing } & Equal variances assumed & 0.631 & 0.428 & -1.868 & 238 & 0.063 \\
\hline & $\begin{array}{l}\text { Equal variances not } \\
\text { assumed }\end{array}$ & & & -1.868 & 235 & 0.063 \\
\hline \multirow[t]{2}{*}{ Toilet } & Equal variances assumed & 34.631 & 0.000 & -4.345 & 238 & 0.000 \\
\hline & $\begin{array}{l}\text { Equal variances not } \\
\text { assumed }\end{array}$ & & & -4.345 & 226 & 0.000 \\
\hline \multirow{2}{*}{$\begin{array}{l}\text { Liquid waste } \\
\text { disposal }\end{array}$} & Equal variances assumed & 30.908 & 0.000 & -3.324 & 238 & 0.001 \\
\hline & $\begin{array}{l}\text { Equal variances not } \\
\text { assumed }\end{array}$ & & & -3.324 & 225 & 0.001 \\
\hline \multirow{2}{*}{$\begin{array}{l}\text { Solid waste } \\
\text { disposal }\end{array}$} & Equal variances assumed & 4.554 & 0.034 & -1.289 & 238 & 0.199 \\
\hline & $\begin{array}{l}\text { Equal variances not } \\
\text { assumed }\end{array}$ & & & -1.289 & 232 & 0.199 \\
\hline \multirow{2}{*}{$\begin{array}{l}\text { Source of } \\
\text { drinking water }\end{array}$} & Equal variances assumed & 27.642 & 0.000 & -1.639 & 238 & 0.103 \\
\hline & $\begin{array}{l}\text { Equal variances not } \\
\text { assumed }\end{array}$ & & & -1.639 & 213 & 0.103 \\
\hline
\end{tabular}

The field data indicate that $27.5 \%, 77.5 \%$, and $92.5 \%$ of households dump their solid waste indiscriminately, have no sewerage system to dispose liquid waste; and have access to safe drinking water respectively in the WM. In the OSM however, $26.7 \%$, $60 \%$, and $86.7 \%$ of households respectively dump their solid waste indiscriminately, have no access to sewerage system to dispose liquid waste, and have access to safe drinking water. The independent samples test in Table 3 indicates statistically significant difference between the households' access to 
toilet facilities, mode of disposing liquid waste, and quality of bathing facilities. There is however, no significant difference in the drinking water quality and solid waste disposal means between the municipalities.

\section{Land Use Controls and the State of Housing in the Municipalities}

Planning controls are essential for the realization of improved housing, neighborhood quality, and housing adequacy. Unfortunately, the Wa Municipal Assembly (WMA) and the Offinso South Municipal Assembly (OSMA) have not adequately enforced their planning controls. The field data show that $40.7 \%$ and $56.2 \%$ of property owners in the WM and OSM respectively did not apply for building permit before building their housing units. Similarly, $87.1 \%$ and $81.7 \%$ of the respondents whose permit applications were declined disregarded the WMA's and OSMA's decisions respectively.

The approved houses in both municipalities generally tend to have basic housing facilities compared to the unapproved properties. The data indicate that $73.7 \%$ and $78.9 \%$ of authorized houses respectively in the WM and OSM have in-house bathing facilities. However, $57.1 \%$ and $50 \%$ of unauthorized properties respectively in the WM and OSM have in-house bathhouse. Also, $33.3 \%$ and $71.1 \%$ of approved houses correspondingly in the WM and OSM have inhouse toilet facilities compared to $18.8 \%$ and $37.5 \%$ of unapproved houses respectively in the WM and OSM that have in-house toilet facilities. The data suggest that efficient planning regime have the potential to enhance the housing conditions in the municipalities.

It is striking to note however, that $26.3 \%$ and $66.7 \%$ of authorized houses in the WM correspondingly has no internal bathrooms and toilets; and $21.1 \%$ and $28.9 \%$ of the approved properties in the OSM respectively lack bathrooms and toilets in-house. This is puzzling since toilets and bathing facilities are basic requirements for building permit approvals under section 135 (1 and 5) of the National Building Regulation (LI 1630), 1996. It is unlikely that the planning authorities will approve proposed developments in contravention of the LI 1630. Some developers however, convert the proposed toilets and bathrooms to sleeping rooms after the approval of their permit applications to meet the accommodation needs of their households, kins or to earn extra rental incomes. This flouting of the building permits conditions either goes undetected or unpunished by the planning authorities.

\section{Housing, Land Use Control and Protected Zones in the Municipalities}

The poor conditioning of housing in both the WM and OSM is a significant threat to the sustainability of the environment. Housing problems such as inadequate sewer and sanitation infrastructure have led to severe environmental crisis in both municipalities. Uncontrolled housing development has resorted in the destruction of environmentally sensitive zones (such as wetlands); the conversion of agricultural lands into residential uses; and environmental pollution in both municipalities. There exists significant encroachment on amenity lands such as schools, open spaces and protected ecological zones in the municipalities (Boamah et al., 2012; Boamah, 2013). The loss of prime agricultural lands, wetlands and amenity lands is a major threat to the ecosystem and biodiversity, and has disturbing impact on the ecological balance (Rees, 1992). The protection of environmental fragile lands, ground water, and wetlands are essential for the attainment of sustainable development. They have huge implications for health and livelihoods sustainability.

The deprived condition of housing and their associated negative impact on the urban environment in the municipalities are partly the outcome of indiscreet land use planning system. The large scale violation of the planning regime is partly responsible for the poor state of housing, the destruction of protected environmental zones, and the indiscriminate waste disposal in the municipalities. A casual inspection in both municipalities shows the construction of houses in waterlogged areas, the blocking of watercourses for housing development, and the pollution of sensitive water bodies in flagrant disregard for the land use regulations. Boamah et al. (2012) and Boamah (2013) reported significant public disdain for the land use planning system in both municipalities. We argue that the planning conditions are generally inconsistent with the socio-economic milieu of most households in the municipalities. They therefore generally disregard the building regulations. This is consistent with Grant and Yankson (2003) and Konadu-Agyemang (2001) who notes that adequate housing delivery in Ghana has been constrained by outmoded planning and building legislations. 
The field data indicate a general indiscipline which has resulted to an enormous muddle in the built environment. The indiscipline has led to incompatible land uses, inaccessible neighborhoods, and unsustainable development in the municipalities. The resulting effect is unclean and unsafe living environments with their potentially negative impacts on the health status of the municipalities' residents. The nonenforcement and non-adherence to planning controls have worked against the provision of adequate housing to households and ecosystem protection in both municipalities.

\section{Conclusion}

The Wa and Offinso South municipalities are characterized by housing inadequacy. The State lacks the capability to provide adequate shelter to all its citizens. Households' delivery of housing is also insufficient and is associated with high degree of informality. Most households live in degraded environments; inaccessible and haphazardly developed neighborhoods; and housing units without adequate waste disposal mechanisms. Overcrowding and congestion also typifies the housing environment in these municipalities. These pose serious environmental and health hazards to the residents of the municipalities. It is suggested that the OSMA focuses on the high state of indiscriminate defecation whilst the WMA pay more attention to improper waste disposal.

\section{Recommendations}

Policy intervention should address the question of housing adequacy and not just the housing need-stock gap. Policy makers must have full appreciation of the linkages between housing, and health and other social outcomes of households; and environmental sustainability. Health and sanitation related issues in housing must be prioritised by municipalities and state policy interventions in addressing the housing problem. There must be a sustained campaign against all forms of environmentally unfriendly activities such as indiscriminate defecation and disposal of solid waste. The campaign must focus on properly stigmatizing such irresponsible acts in order to discourage people from them. That is, social force must be employed to ensure cleaner living environments. The legal system must also be used alongside the social controls to adequately sanction residents who engage in environmentally offending acts. The municipal authorities should focus on in-house toilet and bathing facilities and de-emphasize public toilet provisions. They should strictly enforce regulations requiring developers to provide toilet and bathing facilities in-house in new housing developments.

\section{References}

Alcamo, J., Florke, M., and Marker, M. (2007), "Future Long-term Changes in Global Water Resources driven by Socio-economic and Climatic Change', Journal of Hydrological Science, 52, 247-275.

Adarkwa, K. K. and Oppong, R. A. (2007), "Poverty Reduction through the Creation of a Liveable Housing Environment: A case study of Habitat for Humanity International Housing Units in Rural Ghana”, Property Management, 25(1), 7-26.

Asomani-Boateng, R. (2007), "Closing the Loop Community-Based Organic Solid Waste Recycling, Urban Gardening, and Land Use Planning in Ghana, West Africa", Journal of Planning Education and Research, (27), 132145.

Boadi, K., Kuitunen, M., Raheem, K., and Hanninen, K. (2005), "Urbanisation without Development: Environmental and Health Implications in African Cities", Environment, Development and Sustainability, 7(4), 465-500.

Boamah N.A. (2009), "Secondary Mortgage Market Market (SMM): Is it Right for Financing Housing in Ghana?, Journal of Science and Technology, 29(1), 17-27.

Boamah, N.A. (2010), "Housing Affordability in Ghana: a Focus on Kumasi and Tamale", Ethiopian Journal of Environmental Studies and Management, 3(3), 1-11.

Boamah, N.A. (2013), Land use controls and residential land values in the Offinso South municipality, Ghana. Land Use Policy (2013).

Boamah, N. A., Gyimah, C., and Nelson, J.K.B. (2012), "Challenges to the Enforcement of Development Controls in the Wa municipality", Habitat International, 36(1), 136-142.

Bonnefoy, X., Braubach, M., Krapavickaite, D., Ormand, D., Zurlyte, I. (2003), "Housing Conditions and Self-reported Health Status: A Study in Panel Block Buildings in Three Cities in Eastern Europe", Journal of Housing and the Built Environment; 18(4), 329-352.

Coffman, M. and Umemoto, K. (2010), "The Triple-bottom-line: Framing of trade-offs in Sustainability Planning Practice", Environment, Development and Sustainability, 12, 597- 610. 
Deng, L. (2007), "Comparing the Effects of Housing Vouchers and Low-Income Housing Tax Credits on Neighborhood Integration and School Quality", Journal of Planning Education and Research, 27, 20-35.

Fawaz, M. (2009), "Contracts and Retaliation Securing Housing Exchanges in the Interstice of the Formal/Informal Beirut (Lebanon) Housing Market", Journal of Planning Education and Research, 29, 90-107.

Galster, G. and Tatian, P. (2009), "Modeling Housing Appreciation Dynamics in Disadvantaged Neighborhoods", Journal of Planning Education and Research, 29, 7-22.

Grant, R. and Yankson, P. (2003), "City Profile: Accra", Cities, 20(1), 65-74.

Heywood, A., (2011), The End of the Affair: Implications of Declining Home Ownership. London: Smith Institute.

Karamujic, M. H. (2011), "Some Empirical Evidence on Variations in Australian Housing Finance Commitments", Property Management, 29(4), 330-344.

Konadu-Agyemang, K. (2001), "A Survey of Housing Conditions and Characteristics in Accra, an African City", Habitat International, 25, 15-34.

Kupke, V. and Rossini, P. (2011), "Housing Affordability in Australia for First Homebuyers on Moderate Incomes", Property Management, 29(4), 357-370.

Levine, J. (1998), "Rethinking Accessibility and Jobs-housing Balance", Journal of the American Planning Association, 64,133-49.

Lwasa, S. (2004), Urban Expansion Processes of Kampala in Uganda: Perspectives on contrasts with cities of developed countries, Panel Contribution, Population-Environment Research Network (PERN) Cyberseminar on Urban Spatial Expansion, 29 November - 15 December 2004.

Moore, M., Gould, P., and Keary, B. S. (2003), "Global Urbanization and Impact on Health", Int J. of Hygiene and Environmental Health, 206, 269-78.

Mueller, E. J., Bell, H., Chang, B. B. and Henneberger, J. (2011), "Looking for Home after Katrina: Post disaster Housing Policy and LowIncome Survivors", Journal of Planning Education and Research, 31(3), 291-307.
Nsiah-Gyabaah, K. (2004), Urbanization Processes - Environmental and Health effects in Africa, Panel Contribution, PopulationEnvironment Research Network (PERN) Cyberseminar on Urban Spatial Expansion, 29 November - 15 December 2004.

Obeng-Odoom, F. (2009), The future of our cities. Cities, 26(1), 49-53.

Olanrewaju, R. M. (2009), "The Climate Effect of Urbanization in A City of Developing Country: The Case Study Of Ilorin, Kwara State", Nigeria, Ethiopian Journal of Environmental Studies and Management, 2(2), 67-72.

Oteng-Ababio, M. (2012), "Neglected Vulnerabilities in a Rapidly Urbanizing City: Reflections on Earthquake Risks in Accra", Journal of Housing and the Built Environment, 27, 187-205.

Owusu, S.E. and Boapeah, S.N. (2003), "Housing Policy in Ghana: Experiences and Interventions for Public/Private Sector Support Systems". Bi-Annual Journal of the Building and Road Research Institute (CSIR), Ghana, Vol. 8, No. 1.

Pavri, F., Springsteen, A., Dailey, A., and MacRae, J. D. (2012), "Land Use and Socioeconomic Influences on a Vulnerable Freshwater Resource in Northern New England, United States", Environment, Development and Sustainability, 1-19.

Rees, W (1992), "Ecological Footprints and Appropriate Carrying Capacity: What urban Economics Leave Out", Environment and Urbanization, 4(2), 121-129.

Schively, C. (2008), "Sustainable Development as a Policy Guide: an Application to Affordable Housing in Island Communities", Environment, Development, and Sustainability, 10, 769-786.

United Nations Human Settlements Programme (2010), The state of African cities: governance, Inequality and Urban land markets. UNHABITAT:Nairobi

Whitehead, C. M. E. (2007), "Planning Policies and Affordable Housing: England as a Successful Case Study? Housing Studies, 22(1), 25-44. 